\title{
Dendroarchaeological analysis of the Terminal Warehouse in New York City reveals a history of long-distance timber transport during the Gilded Age
}

\author{
Caroline Leland $^{\mathrm{a}, *, 1}$, Mukund Palat Rao ${ }^{\mathrm{a}, \mathrm{b}, \mathrm{c}, *, 1}$, Edward R. Cook ${ }^{\mathrm{a}}$, Benjamin I. Cook ${ }^{\mathrm{d}, \mathrm{e}}$, \\ Bryan M. Lapidus ${ }^{\mathrm{f}}$, Andrew B. Staniforth ${ }^{\mathrm{f}}$, Alan Solomon ${ }^{\mathrm{g}}$, Marguerite Y. Holloway ${ }^{\mathrm{h}}$, \\ Milagros Rodriguez-Caton ${ }^{\mathrm{a}}$ \\ ${ }^{a}$ Tree Ring Laboratory, Lamont-Doherty Earth Observatory of Columbia University, Palisades, NY 10964, United States \\ ${ }^{\mathrm{b}}$ Cooperative Programs for the Advancement of Earth System Science, University Corporation for Atmospheric Research, Boulder, CO 80301, United States \\ ${ }^{c}$ Department of Plant Science, University of California, Davis, CA 95616, United States \\ ${ }^{\mathrm{d}}$ NASA Goddard Institute for Space Studies, New York, NY 10025, United States \\ e Ocean \& Climate Physics, Lamont-Doherty Earth Observatory of Columbia University, Palisades, NY 10964, United States \\ ${ }^{\mathrm{f}}$ L\&L Holding Company, LLC, NY 10019, United States \\ ${ }^{8}$ Sawkill Lumber, LLC, Brooklyn, NY 11238, United States \\ ${ }^{\mathrm{h}}$ School of Journalism, Columbia University, New York, NY 10027, United States
}

\section{A R T I C L E I N F O}

\section{Keywords:}

Dendroprovenance

Longleaf pine

Yellow pine

Pinus palustris

Southeast US

\begin{abstract}
A B S T R A C T
The Gilded Age of the late 19th century marked a period of rapid development and urbanization in New York City, U.S. To accommodate the high demand in wood products during that time, the timbers used for development of the city were increasingly sourced from locations distant from the northeastern United States. The Terminal Warehouse in the Chelsea neighborhood of New York City was one of many large buildings erected during this period of city expansion, and is an important symbol of New York City commerce during the late 1800s. To determine the history and provenance of timbers used in the construction of the Terminal Warehouse, we used tree-ring analysis on longleaf pine (Pinus palustris Mill.) joists that were original to the building. The ring-width patterns on the joists crossdated well internally, suggesting a common origin of the sampled lumber. Further, our Terminal Warehouse tree-ring chronology (1512-1891 C.E.) correlated strongly with existing treering chronologies from western/central Georgia and eastern Alabama, indicating that the timbers were extracted from this region of the southeastern United States. The provenancing and dating of the Terminal Warehouse timbers underscores the important role that southern pines played in the expansion and development of New York City during the Gilded Age.
\end{abstract}

\section{Introduction}

The Terminal Warehouse building is located between 11th and 12th Avenue and 27th and 28th street in the West Chelsea Historic District of lower Manhattan, New York City (NYC), New York, U.S. (Fig. 1). The warehouse was built by William W. Rossiter in the early 1890s (King, 1893), a time of rapid industrialization of the New York City region, and is comprised of 25 sub-buildings (Burrows and Wallace, 1999). A large majority of these units were originally used to store wines, liquors, rubber, fur, rugs, robes, and Broadway theatre sets, while four units functioned as United States bonded warehouses (King, 1893; Miller, 2012). At the time of its construction during the late 19th century, private refrigeration was uncommon and the building was one of few that offered cold storage facilities. The signage advertising its cold storage facilities is still visible on the facade of the building (Fig. 1). The tracks of the New-York Central Railroad and the Hudson River Railroad ran directly into the building, and its western end included a pier into the Hudson River facilitating the easy loading and unloading of goods

\footnotetext{
* Corresponding authors at: Tree Ring Laboratory, Lamont-Doherty Earth Observatory of Columbia University, Palisades, NY 10964, United States (C. Leland and M.P. Rao).

E-mail addresses: cleland@1deo.columbia.edu (C. Leland), mukund@ldeo.columbia.edu (M.P. Rao).

1 The authors contributed equally to this manuscript.
} 

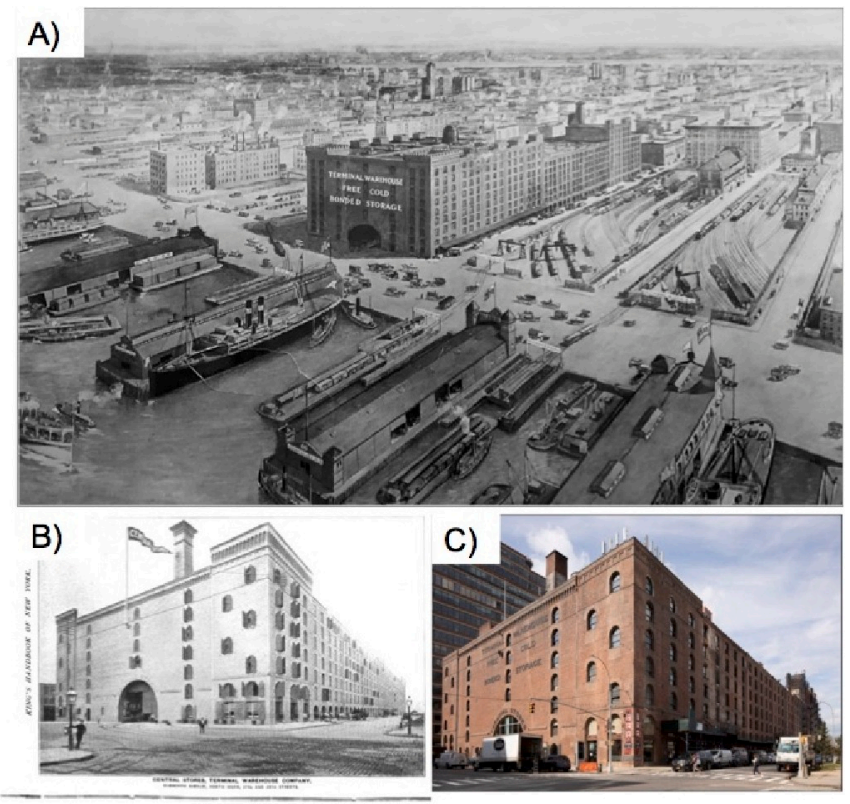

Fig. 1. Historic and modern photographs of the Terminal Warehouse in Chelsea, New York City, NY, U.S. Panel A) shows an artistic rendering of the westfacing view of the Terminal Warehouse from the year 1912 along the Hudson River (New York (N.Y.). Department of Docks and Ferries, 1906). Close observation of image A) shows the presence of railroad tracks connecting the pier in the Hudson River to the interior of the Warehouse. Panels B) and C) show the eastern face of the Terminal Warehouse from 1892 (King, 1893) and 2019 (credit: Terminal Fee Owner, LP), respectively. Close observation of image B) shows a freight train in the process of exiting the Terminal Warehouse onto 28th St. and 11th Avenue in New York City.

into the Warehouses' storage units (Fig. 1; King, 1893; See Plate 14 in Lionel Pincus and Princess Firyal Map Division, 1885; Miller, 2012). The immense scale of the building with close to $0.1 \mathrm{~km}^{2}$ (1 million sq. $\mathrm{ft}$.) of real estate space, along with its easy accessibility to shipping, rail transportation, warehousing, and packing, made the Terminal Warehouse a key symbol of the development of New York City in the late 19th and early 20th centuries.

The expansion of urban centers like New York City in the late 19th century, the so-called Gilded Age in the U.S. (Stiglitz, 2015), depended on vast amounts of wood for construction, fuel, charcoal, railroad ties, and ship building. Many buildings in New York City erected during that period were constructed using lumber from old-growth forests; these timbers were valuable construction materials due to their high density, hardness, and strength (Bergsagel and Lynch, 2019). White pine (Pinus strobus L.) along with other northern conifers (e.g., spruce, hemlock, and fir), and southern longleaf pine (Pinus palustris Mill.) were commonly used. This demand for timber contributed to the widespread deforestation of the eastern United States (Pfaff, 2000) and a notable loss of oldgrowth forests. Near the turn of the 20th century, the northeastern U.S. had lost the vast majority of its original stands of forest (Kellogg, 1909). Consequently, the wooden construction materials for many of the buildings constructed during this era were sourced from regions distant from New York.

In the case where the source of timber from a building is of interest but written records are not available, tree-ring analysis can be performed to reveal the specific history of construction. The use of tree-ring records to determine the geographic origin, age, and general history of woody material from various structures has been practiced since the early 20th century (e.g., Douglass, 1929; Hawley, 1934), and is broadly referred to as dendroarchaeology (Speer, 2010). Specifically, dendroprovenancing refers to the use of dendrochronological methods to locate the region of origin of wooden material (Bridge, 2012; Eckstein and Wrobel, 2007). Once the tree species utilized for construction has been identified, standard methods of dendroprovenancing typically rely on i.) the presence of unique micro-climatic fluctuations at the source location that facilitates the development of a crossdated chronology, and ii.) an established network of chronologies that aid in exactly dating the timbers and determining the proximate provenance location (Domínguez-Delmás, 2020; Pearl et al., 2020). To name a few modern examples, dendroprovenancing has been used to successfully locate the source of wooden material found in shipwrecks on the Iberian Peninsula (Domínguez-Delmás et al., 2013) and of a buried shipwreck under the former World Trade Center building of New York City (Martin-Benito et al., 2014), as well as to understand timber procurement by Ancestral Puebloan people at Chaco Canyon (Guiterman et al., 2016), and to decipher the construction history of colonial era buildings in the northeastern U.S. (Krusic et al., 2004).

Historical records of timber procurement are not available for many notable late 19 th and early 20th century structures in New York City. To better understand the history of the Terminal Warehouse, here we use dendrochronology to provenance and date the timber material used in the construction of the building. This analysis will shed light on the specific sourcing of timbers for the Terminal Warehouse, an archetypal example of New York City construction during this era. In doing so, we will provide a perspective on timber transport and the logging industry that facilitated the rapid development of New York City in the late 19th century.

\section{Material and methods}

Tree-ring samples were collected from the Terminal Warehouse in the Chelsea neighborhood of New York City in June and July of 2019. We collected cross-sections from several remnant joists from the original construction that had been disassembled and were being stored in the cellar of the Terminal Warehouse (Fig. 2). We selectively sampled 22 joists that i) were considered to have a sufficient number of rings for dendrochronological analysis (at least $\sim 150$ visible rings); ii) preferably contained bark or sapwood for a better estimate of felling dates; and iii) were accessible for safe cutting with the chainsaw. All of the sampled joists were likely installed around the same time, soon after the building permit was issued in June of 1890. That said, there were certain areas of the Terminal Warehouse that were reconstructed after damage from fires in 1902 and 1912 (New York Times, 1902; New York Times, 1912).

The tree-ring samples were taken to Columbia University's LamontDoherty Earth Observatory Tree-Ring Laboratory in Palisades, New York, for standard dendrochronological processing (Stokes and Smiley, 1968). We determined that the timbers collected from the Terminal Warehouse were longleaf pine (Pinus palustris Mill.) due to the high resin content, pronounced latewood banding with varying widths, and pencilsized pith of the samples (Wahlenberg, 1946), (Fig. 2). The samples were dried and sanded with progressively finer sandpaper so that the rings

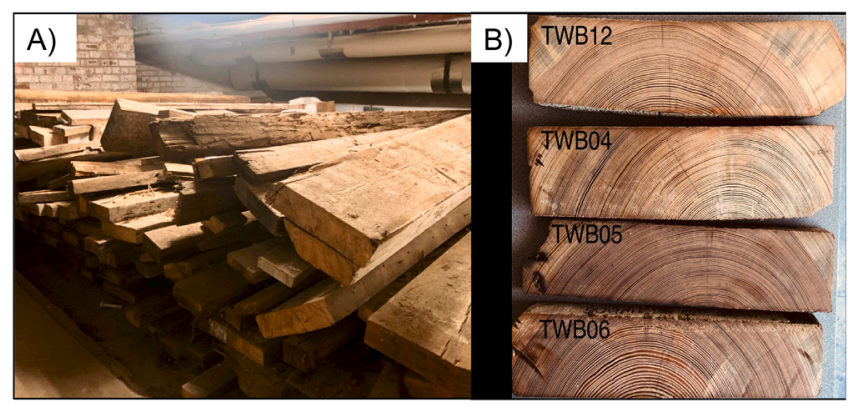

Fig. 2. A) Remnant longleaf pine joists stored in the basement of the Terminal Warehouse in Chelsea, New York City; B) Four joist timbers (TWB04, TWB05, TWB06, and TWB12) after being cut, sanded, and prepared for dendrochronological analysis. 
were clearly visible for inspection under a stereoscope. The rings on each cross-section were initially counted along two radii and visually crossreferenced to ensure all rings were counted. A single radius on each cross-section was measured as undated (i.e., arbitrary pseudo-dates were assigned) to a precision of $\pm 0.001 \mathrm{~mm}$ using a sliding measuring stage and the program MeasureJ2X. The undated tree-ring series were then collated and internally cross-dated against one another both visually and using the program COFECHA (Holmes, 1983). Based on this analysis, measured series were temporally shifted to produce an undated chronology. Each series was detrended using a cubic smoothing spline with a $50 \%$ wavelength cutoff at 32 years to obtain tree-ring indices (Cook and Peters, 1981) and we calculated the biweight robust mean of the indices to develop the undated Terminal Warehouse master chronology.

To provenance the Terminal Warehouse samples, the undated chronology was compared against several existing longleaf pine treering chronologies. The native range of longleaf pine is in the southeastern United States (Fig. 3), therefore we hypothesized that the timbers were likely harvested from this region soon before being transported to New York City. To determine where within this region the timbers likely originated, we compared the undated Terminal Warehouse master chronology with nine reference chronologies from five states: Alabama $(n=1)$, Georgia $(n=4)$, Louisiana $(n=1)$, North Carolina ( $\mathrm{n}=2$ adjacent sites), and Virginia $(\mathrm{n}=1)$ (Fig. 3). All chronologies are longleaf pine, though the single chronology from Virginia was derived from a compilation of dendroarchaeological collections and is composed of several regional pine species. Chronology comparisons between the Terminal Warehouse chronology and the reference chronologies were performed by calculating the nonparametric Spearman's rank correlation coefficient for 50-year periods with 25-year overlaps in the program COFECHA (Holmes, 1983), and we assessed the highest correlations across all site comparisons and overlapping periods to date the Terminal Warehouse chronology.

As an additional analysis for provenancing the timbers, we compared the master Terminal Warehouse chronology against the North American Drought Atlas (NADA - Cook et al., 2004; Cook et al., 2010) using nonparametric Spearman's rank correlation coefficients to identify the general region that most strongly correlated with the warehouse timbers. These correlations were calculated on a grid-cell-by-grid-cell basis between the final dated Terminal Warehouse chronology and the NADA

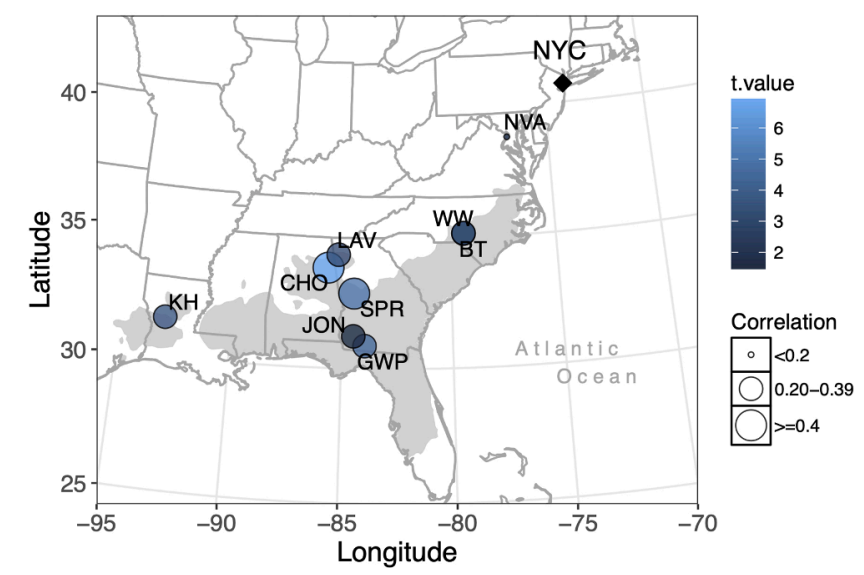

Fig. 3. Locations of longleaf pine (Pinus palustris) chronologies compared against the Terminal Warehouse master chronology located in New York City (NYC; black diamond). The size of the circles corresponds to the Spearman's rank correlation coefficient between the Terminal Warehouse chronology and each site, and the shade of blue represents the t-value for the same comparisons (see Table 2 for site codes, correlations, and t-values). The natural distribution range of longleaf pine based on Little (1971) is shown in light gray. Note that the NVA chronology is a compilation of several different pine species and regional dendroarchaeological sites throughout Virginia. using their common period of overlap (1670-1891, see results).

\section{Results}

Of the 22 longleaf pine joists that were sampled from the Terminal Warehouse, 16 samples could be internally crossdated (Table 1). The crossdated series ranged in length from 114 to 268 rings and yielded a Spearman's intercorrelation of $r=0.42$ (Table 1 ). The strong intercorrelation between samples suggests that the joist timbers were likely sourced from a similar region, and thus could be combined into a single master chronology. The final chronology was derived as the bi-weight robust mean of the detrended, internally cross-matched series. Seven of these samples contained sapwood on the outer portion of the joist (Table 1), and one sample (TWB12) appeared to have a waney edge (Fig. 2), allowing us to better estimate the felling date/period of the timbers used in construction.

In comparing the undated Terminal Warehouse chronology with the longleaf pine reference chronologies, the Terminal Warehouse chronology most strongly correlated with Choccolocco Mountain, Alabama (CHO) from 1690 to 1891 C.E. (Spearman's rank-order correlation $\left(r_{s}\right)$ $=0.44, \mathrm{p}<0.01, \mathrm{t}=6.9, \mathrm{n}=202$ ), followed closely by Spreewell Bluff, Georgia (SPR) from 1754 to 1891 C.E. $\left(r_{s}=0.40, p<0.01, t=5.1, n=\right.$ 138; Table 2, Fig. 3). In both cases, the strongest statistical matches yielded an outermost date of 1891 for the Terminal Warehouse chronology. The Choccolocco Mountain and Spreewell Bluff sites are located near one another along the border between Georgia and Alabama (Fig. 3), and when we averaged their chronologies, the correlation with the Terminal Warehouse chronology increased $\left(\mathrm{r}_{\mathrm{s}}=0.54, \mathrm{p}<0.01\right.$, 1690-1891 C.E., $\mathrm{t}=$ 9.1, $\mathrm{n}=202$; Table 2, Fig. 4).

The full Terminal Warehouse chronology extends back to 1512 with an outermost date of 1891, and the years 1612-1890 consist of two or more series (Fig. 4a-b). The common signal of the detrended series as measured by the Expressed Population Signal (EPS: Wigley et al., 1984) is strongest $(>0.70)$ from around 1670-1815, but weakens slightly before and after those dates due to a decline in sample size (Fig. 4b). Therefore, for the correlation analyses with all sites, we truncated the Terminal Warehouse chronology at 1670, when the sample depth drops below ten series.

The dates of individual series based on an outermost chronology date of 1891 are shown in Table 1. Only one series reached an outermost date of 1891 (TWB12), though two other samples had an outer ring close to

Table 1

Joist samples collected from the Terminal Warehouse during the summer of 2019. The presence of sapwood for each series is indicated. The CORREL column refers to correlation of each series against the master chronology based on all dated series from the Terminal Warehouse. The number of crossdated years (\# Years) and the matching period (Dating) corresponding to tree-ring data from Georgia and Alabama (Choccolocco Mountain and Spreewell Bluff sites) are shown. TWB05, 13, 15, 17-18, and 22 remain undated and are excluded from the table.

\begin{tabular}{llllll}
\hline Seq & ID & \# Years & Sapwood & CORREL & Dating \\
\hline 1 & TWB01 & 172 & Yes & 0.410 & $1664-1835$ \\
2 & TWB02 & 149 & No & 0.401 & $1670-1818$ \\
3 & TWB03 & 190 & No & 0.444 & $1613-1802$ \\
4 & TWB04 & 207 & Yes & 0.382 & $1652-1858$ \\
5 & TWB06 & 150 & Yes & 0.515 & $1703-1852$ \\
6 & TWB07 & 127 & Yes & 0.462 & $1731-1857$ \\
7 & TWB08 & 151 & No & 0.370 & $1650-1800$ \\
8 & TWB09 & 182 & Yes & 0.447 & $1709-1890$ \\
9 & TWB10 & 203 & No & 0.281 & $1623-1825$ \\
10 & TWB11 & 196 & Yes & 0.436 & $1694-1889$ \\
11 & TWB12 & 168 & Yes & 0.386 & $1724-1891$ \\
12 & TWB14 & 166 & No & 0.529 & $1669-1834$ \\
13 & TWB16 & 144 & No & 0.473 & $1669-1812$ \\
14 & TWB19 & 114 & No & 0.436 & $1749-1862$ \\
15 & TWB20 & 167 & No & 0.479 & $1639-1805$ \\
16 & TWB21 & 268 & No & 0.327 & $1512-1779$ \\
\hline
\end{tabular}


Table 2

Comparisons between the Terminal Warehouse chronology and nine longleaf pine chronologies (and one chronology averaging two sites) from the eastern United States. The sites are organized alphabetically by the state in which each site is located (AL = Alabama; GA = Georgia; $\mathrm{LA}=$ Louisiana; NC $=$ North Carolina; VA = Virginia). "FY" and "LY" indicate the first and last year of the chronology comparison, respectively, and " $N$ " refers to the number of years compared. The first compared year was contingent on at least 5 trees and a strong signal strength for both sites. The Spearman's rank correlation coefficient $\left(r_{s} ; * \mathrm{p} \leq 0.01\right)$ and $t$-value $(t)$ for each chronology comparison are shown.

\begin{tabular}{|c|c|c|c|c|c|c|c|}
\hline $\begin{array}{l}\text { P. palustris } \\
\text { Chronology } \\
\text { (U.S. State) }\end{array}$ & Code & $\mathrm{FY}$ & LY & $\mathrm{N}$ & $\begin{array}{l}\mathrm{r}_{\mathrm{s}} \\
\left({ }^{*} \operatorname{sig}\right)\end{array}$ & $\mathrm{t}$ & $\begin{array}{l}\text { Originator/ } \\
\text { (Reference) }\end{array}$ \\
\hline $\begin{array}{l}\text { Choccolocco } \\
\text { Mountain } \\
\text { (AL) }\end{array}$ & $\mathrm{CHO}$ & 1690 & 1891 & 202 & $0.44^{*}$ & 6.9 & $\begin{array}{l}\text { Bale, A.; } \\
\text { Stambaugh } \\
\text { M.C.; } \\
\text { Guyette, R.P.; } \\
\text { Marschall, J. } \\
\text { M./(Guyette } \\
\text { et al., 2012) }\end{array}$ \\
\hline $\begin{array}{l}\text { Greenwood } \\
\text { Plantation } \\
\text { (GA) }\end{array}$ & GWP & 1739 & 1891 & 153 & $0.34 *$ & 4.5 & $\begin{array}{l}\text { Knight. T.A./( } \\
\text { Pederson } \\
\text { et al., 2012) }\end{array}$ \\
\hline $\begin{array}{l}\text { Jones } \\
\text { Ecological } \\
\text { Research } \\
\text { Center (GA) }\end{array}$ & JON & 1844 & 1891 & 48 & 0.23 & 1.6 & $\begin{array}{l}\text { Pederson, N.; } \\
\text { Palik, B.; } \\
\text { Mitchell, R. }\end{array}$ \\
\hline $\begin{array}{l}\text { Lavender } \\
\text { Mountain } \\
\text { (GA) }\end{array}$ & LAV & 1820 & 1891 & 72 & $0.37^{*}$ & 3.4 & $\begin{array}{l}\text { Knight, T.A./( } \\
\text { Pederson } \\
\text { et al., 2012) }\end{array}$ \\
\hline $\begin{array}{l}\text { Spreewell } \\
\text { Bluff (GA) }\end{array}$ & SPR & 1754 & 1891 & 138 & $0.40^{*}$ & 5.1 & $\begin{array}{l}\text { Knight, T.A./( } \\
\text { Pederson } \\
\text { et al., 2012) }\end{array}$ \\
\hline $\begin{array}{l}\text { Kisatchie Hills } \\
\text { (LA) }\end{array}$ & $\mathrm{KH}$ & 1670 & 1891 & 222 & $0.25^{*}$ & 3.8 & $\begin{array}{l}\text { Stambaugh } \\
\text { M.C.; } \\
\text { Guyette, R.P.; } \\
\text { Marschall, J. } \\
\text { M/(Guyette } \\
\text { et al., 2012) }\end{array}$ \\
\hline $\begin{array}{l}\text { Boyd Tract } \\
\text { (NC) }\end{array}$ & BT & 1711 & 1891 & 181 & $0.22 *$ & 3.0 & $\begin{array}{l}\text { Cook, E.R.; St. } \\
\text { George, S./( } \\
\text { Cook and St. } \\
\text { George, } \\
\text { 2013) }\end{array}$ \\
\hline $\begin{array}{l}\text { Weymouth } \\
\text { Woods (NC) }\end{array}$ & WW & 1690 & 1891 & 202 & $0.23^{*}$ & 3.3 & $\begin{array}{l}\text { Barefoot, A. } \\
\text { C./(Barefoot, } \\
\text { 1997) }\end{array}$ \\
\hline $\begin{array}{l}\text { Northern } \\
\text { Virginia } \\
\text { Combined } \\
\text { (VA) }\end{array}$ & NVA & 1670 & 1849 & 180 & 0.16 & 2.2 & $\begin{array}{l}\text { Cook, E.R./( } \\
\text { Cook et al., } \\
\text { 2010) }\end{array}$ \\
\hline $\begin{array}{l}\text { Choccolocco } \\
\text { Mountain } \\
\text { and } \\
\text { Spreewell } \\
\text { Bluff } \\
\text { Combined } \\
\text { (AL \& GA) }\end{array}$ & - & 1690 & 1891 & 202 & $0.54^{*}$ & 9.1 & - \\
\hline
\end{tabular}

this date (1889 and 1890 for TWB11 and TWB09, respectively). These three samples had a considerable proportion of sapwood and TWB12 appeared to have a waney edge.

A spatial correlation analysis of the Terminal Warehouse chronology with the NADA from 1670 to 1891 further shows that the ring-width patterns on the joist samples most strongly correlate with tree-ring data from central and western Georgia, near Atlanta, as well as the border of Alabama (Fig. 5). The Spearman's rank correlation coefficients steadily decrease in strength when progressing away from this region. When calculating correlations between the Terminal Warehouse chronology and the NADA from 1670 to 1825 , when the sample depth remains at $\mathrm{n}=10$, the same spatial correlation patterns emerge, but the correlations are slightly higher (see Fig. 5 caption). The NADA does not include either of the two reference chronologies used to date the Terminal Warehouse timbers (Choccolocco Mountain nor Spreewell Bluff)
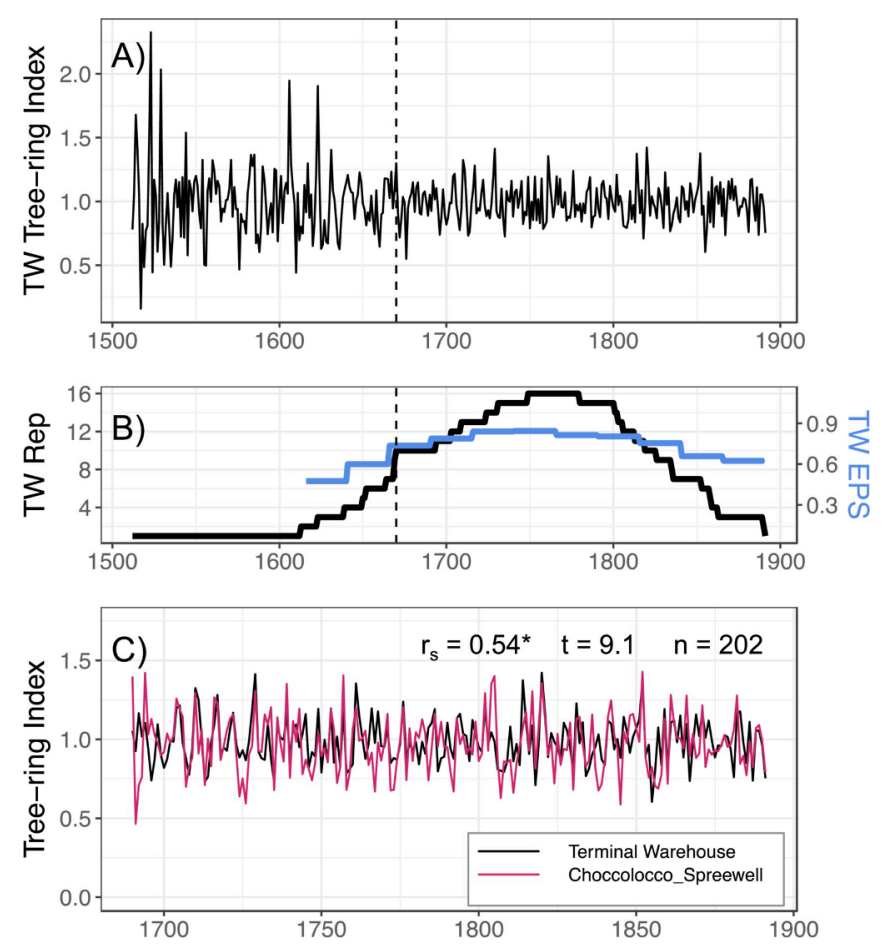

Fig. 4. A) The Terminal Warehouse (TW) master chronology from 1512 to 1891. B) The number of samples comprising the Terminal Warehouse chronology through time (black), and the Expressed Population Signal (EPS) for 50year periods with a 25-year overlap (blue). The dashed line on panels A and B represents the year 1670, when the Terminal Warehouse sample size drops below 10 and the EPS weakens. C) A comparison of the Terminal Warehouse master chronology (black) and a master reference chronology (magenta) combining sites Choccolocco Mountain (eastern Alabama) and Spreewell Bluff (western Georgia) from 1690 to $1891 . \mathrm{r}_{\mathrm{s}}=$ Spearman's correlation; * $=\mathrm{p}<$ $0.01 ; \mathrm{t}=\mathrm{t}$-value; $\mathrm{n}=$ number of years for comparison.

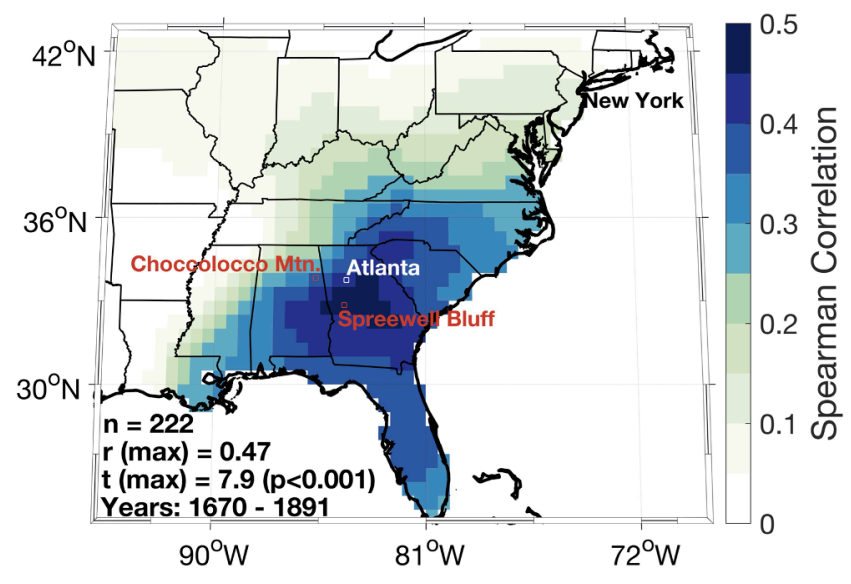

Fig. 5. Spearman's rank correlations between the Terminal Warehouse master chronology and the North American Drought Atlas (NADA) from 1670 to 1891. The location of the two chronologies that correlated most strongly with the Terminal Warehouse chronology are shown in red. $r$ (max): maximum Spearman's rank correlation; $\mathrm{t}(\max )$ : $\mathrm{t}$-value for $\mathrm{r}(\max ) ; \mathrm{n}=$ number of years of overlap. These spatial correlations strengthen further to an $\mathrm{r}(\max )$ of 0.5 and $\mathrm{t}$ $(\max )$ of $7.1(\mathrm{p}<0.001)$ if the Terminal Warehouse chronology is truncated between 1670 and 1825, the section with a sample depth of at least 10 samples. 
and therefore represents a comparison with an independent dataset. The NADA also consists of a network of many tree-ring chronologies developed from other tree species and thus confirms our provenancing results from individual site comparisons.

\section{Discussion}

The results of this study suggest that at least some of the timbers used for construction of the Terminal Warehouse were felled in the late 1800s from the western/central Georgia and eastern Alabama region. This is a relatively inland portion of the natural range of the longleaf pine (Fig. 3), where these trees tend to grow on dry, mountainous slopes (Finch et al., 2012; Outcalt, 2000). Many of the joist samples (i.e., at least 16 of the 22 that could be crossdated) had a high intercorrelation (mean series intercorrelation $=0.42$ ), indicating that lumber from these joists were harvested from the same or nearby site(s).

The building permit for the Terminal Warehouse was documented in June of 1890 and the building was erected in 1891 (King, 1893). Three of the 16 dated samples had an outer ring year close to this known construction period of the Terminal Warehouse and also had a large proportion of preserved sapwood (TWB09: 1890; TWB11: 1889; TWB12: 1891). Thus, these samples were likely harvested around the time of construction. TWB12 in particular appeared to have a rounded/waney edge, suggesting that the outer portion of the tree on this sample was preserved and no outer rings were lost. This provides evidence that the lumber used for that joist was cut in 1891. The fact that TWB09, TWB11, and TWB12 have the most recent growth rings of the entire collection, and their dates directly precede or coincide with the known construction period of the Terminal Warehouse, further corroborates our dating results. Based on these results, we speculate that the joists were installed in an early phase of construction, and that at least some of the lumber used for other joists were also cut in 1891 . However, we note that four other samples also have sapwood, of which three have outer dates in the 1850s (TWB01: 1835; TWB04: 1858; TWB6: 1852; TWB17: 1857). Since these samples predate the construction of the Terminal Warehouse in 1891, we do not exclude the possibility that some of the joists were sourced from stockpiled logs or reused timbers from the same or a nearby site.

The use of longleaf pine for construction of the Terminal Warehouse is not surprising. In fact, southern longleaf pine surged as an important construction material after the U.S. Civil War between 1861-1865 (Smith et al., 2000; Wahlenberg, 1946). Southern pine had a reputation of being sappy, hard, difficult to paint, and likely to warp (Fickle, 2014; Williams, 1989); however, the strength, scale, and abundance of longleaf eventually overshadowed these concerns and it became a widespread construction material. In New York City, longleaf pine was used for area warehouses and factories, to frame high-end uptown residences, and to construct important landmarks and structures, such as the iconic Brooklyn Bridge and the city's large subway system (Yee, 2015). The wood's beauty and durability also grew in esteem for residences; narrow refined cuts of pine, called 'comb grade', were prized for row house floors.

Due to growing demand during the late 19th and early 20th centuries, yellow pine (including longleaf) became the most harvested trees in the U.S. by a wide margin, and contributed nearly $30 \%$ of all lumber logged each year in the country (Finch et al., 2012; Kellogg, 1909; Stambaugh et al., 2021). By that point, much of the red and white pine of New England and the Lake States had been heavily harvested, resulting in a migration of the logging industry to the pine forests of the southern United States (Croker, 1979; Smith et al., 2000). The intensive period of longleaf pine logging followed the expansion of steam technology used for logging railroads, steam skidders and sawmills (Frost, 1993; Smith et al., 2000; Wahlenberg, 1946). From 1880 to 1890, isolated railroads were connected and tracks were standardized, leading to a higher efficiency and cost-effectiveness of timber transport, and these advances in technology and transportation resulted in the near decimation of virgin longleaf timber in the Southeastern U.S. from 1870 to 1930 (Frost,
1993).

By the turn of the 20th century, the state of Georgia was the leading producer of yellow pine timber, and contributed twelve percent of the total output in the U.S. (Kellogg, 1909). The extensive extraction of longleaf pine in Georgia during this period led to widespread deforestation in the state. Our 1891 procurement date therefore also coincides well with large-scale extraction of longleaf pine from this particular region. Due to rapid deforestation, by 1910 Georgia had already slipped to the ninth leading producer of yellow pine as the industry was forced to shift westward to Louisiana, Texas, and Mississippi (Kellogg, 1909; Wahlenberg, 1946).

We currently cannot determine with certainty how the timber was transported from the Georgia/Alabama region to New York City for the construction of the Terminal Warehouse. The rail systems and shipping routes during this era were convoluted and rapidly evolving. One hypothesis is that The Sample Lumber Company (later renamed the Kaul Lumber Company) in Hollins, Alabama, near the Talladega National Forest, could have supplied some of the lumber used for construction of the Terminal Warehouse. The Sample Lumber Company was a large logging and sawmill operation in the region (East, 2013). In this scenario, boards could have been loaded onto the Columbus and Western Railroad, which was built through the town of Hollins, AL in 1888. The route then connected with the Anniston and Atlantic Railroad (later acquired by the Louisville and Nashville Railroad in 1890), and then the Georgia Pacific Railroad, linked to the port of Savannah, GA. Savannah was the primary Atlantic seaport in the state of Georgia and was home to an extensive lumber milling and long-distance shipping industry through the 19th century (Eisterhold, 1973). At that point, lumber would have been unloaded by hand (each $3^{\prime \prime}$ X $12^{\prime \prime}$ X $22^{\prime} / 7.6 \mathrm{~cm} \times 30.5$ $\mathrm{cm} \times 6.7 \mathrm{~m}$ joist, weighing close to $250 \mathrm{lbs} / 113 \mathrm{~kg}$ ), and reloaded onto schooner ships, with the boards fed into an opening in the hull (Detroit Publishing Co., 1900-1906). Another possibility is that the lumber was first transported to Savannah via the Shenandoah Valley Route, which had multiple rail lines connecting locations close to the inferred source region of the wood (Matthews-Northrup Company, and Shenandoah Valley Railway Company, 1890), and was then transported to New York City via rail. Knowledge regarding the transport of timbers to New York City during the late 19th century is currently limited, and we encourage more research on this topic to better elucidate the workings of the timber industry during this notable period of rapid development.

Our research highlights the importance of preserving timbers from historic landmarks, as insights gleaned from dendrochronological analysis of original timbers can provide a rich history of a particular place in time. In addition, such tree-ring records can be used for other purposes beyond archaeology, such as for the reconstruction of past climate or ecological conditions in regions where the wood was originally sourced. This potential use of archaeological wood is clearly illustrated by the strong correlation between the Terminal Warehouse and the NADA; this indicates that the recovered timbers contain a strong southeastern US regional drought signal. Outside of dendrochronological research, salvaging wood from old buildings is also important for economic and sustainability reasons. Regarding longleaf pine specifically, New York City is the country's largest repository of lumber from this species due to its extensive inventory of 19th and early 20th century buildings. A portion of this wood is reclaimed from old buildings undergoing demolition each year and is often re-purposed for millwork. The wood is sometimes sent to the southern United States, where longleaf pine remains a cherished part of the region's heritage. In New York City, salvaged and reclaimed longleaf pine is also deeply valued as it represents a piece of the city's history. It is estimated that nearly $14,000 \mathrm{~m}^{3}$ of wood from old-growth trees of various species are removed from demolished buildings in New York City every year (Bergsagel and Lynch 2019). The reusing of salvaged wood not only holds historical significance, but also benefits the environment through reducing both waste and demand for new lumber. 


\section{Conclusions}

We successfully crossdated 16 of the 22 longleaf pine (Pinus palustris) joist samples collected at the Terminal Warehouse in New York City, U. S. through comparing their annual ring-width patterns. The Terminal Warehouse tree-ring chronology developed from these 16 samples showed a strong positive match with two independent longleaf pine chronologies in eastern Alabama and western Georgia when dated to an outer year of 1891, yielding a chronology spanning 1512-1891 C.E. This was further supported by the high spatial correlations between the Terminal Warehouse series and the North American Drought Atlas (NADA) in the same region. The three timber samples with outer dates extending into the 1880s had a large proportion of sapwood suggesting that the outer rings may approximate the cutting period of these timbers. In conclusion, timbers to build the Terminal Warehouse were very likely sourced from the southeastern U.S. in the region of central/western Georgia and eastern Alabama (i.e., near Choccolocco Mountain, AL, Spreewell Bluff, GA, and Atlanta, GA) and cutting dates for individual timbers likely occurred around 1891 or earlier. Our results provide insight on the significance of lumber from distant locations, specifically longleaf pine, on the development of an important New York City landmark, and highlight the value of preserving old timbers from buildings that are being renovated or demolished.

\section{CRediT authorship contribution statement}

Caroline Leland: Methodology, Formal analysis, Investigation, Writing - original draft. Mukund Palat Rao: Methodology, Formal analysis, Investigation, Writing - original draft. Edward R. Cook: Conceptualization, Software, Investigation, Supervision. Benjamin I. Cook: Investigation, Supervision. Bryan M. Lapidus: Project administration, Funding acquisition. Andrew B. Staniforth: Project administration, Funding acquisition. Alan Solomon: Investigation, Writing original draft. Marguerite Y. Holloway: Resources, Writing - review \& editing. Milagros Rodriguez-Caton: Investigation, Writing - review \& editing.

\section{Acknowledgements}

The authors would like to thank all staff at the L\&L Holding Company and Columbia Property Trust that assisted with sample collection at the Terminal Warehouse, especially Christopher Masotto from property management. The authors are also grateful to Neil Pederson (Harvard Forest, Harvard University), Grant Harley (University of Idaho), and Stockton Maxwell (Radford University) for providing insightful suggestions and information. We also thank two anonymous reviewers for their helpful suggestions for improving this manuscript. Funding for the collection and processing of tree-ring samples was provided by L\&L Holding Company, LLC. The tree-ring data and final chronology developed for the study are available at https://www.ncdc.noaa.gov/paleo/st udy/33532. MPR was supported by the NOAA Climate and Global Change Postdoctoral Fellowship Program, administered by UCAR's Cooperative Programs for the Advancement of Earth System Science (CPAESS) under award \# NA18NWS4620043B.

\section{References}

Barefoot, A.C., 1997. In: NOAA/WDS Paleoclimatology - Barefoot - Weymouth Woods State Park - PIPA - ITRDB NC9. NOAA National Centers for Environmental Information. https://doi.org/10.25921/b8ks-3q34.

Bergsagel, D., Lynch, T., 2019. Harvesting New York City -Old-Growth Urban Forestry. The Evolving Metropolis, 20th IABSE Congress, New York City.

Bridge, M., 2012. Locating the origins of wood resources: a review of dendroprovenancing. J. Archaeol. Sci. 39 (8), 2828-2834.

Burrows, E.G., Wallace, M., 1999. Gotham: A History of New York City to 1898. Oxford University Press, New York.
Cook, E.R., Peters, K., 1981. The smoothing spline: a new approach to standardizing forest interior tree-ring width series for dendroclimatic studies. Tree-Ring Bull. 41, 45-53.

Cook, E.R., St. George, S., 2013. In: NOAA/WDS Paleoclimatology - Cook - Boyd Tract PIPA - ITRDB NC019. NOAA National Centers for Environmental Information. https://doi.org/10.25921/a25r-4g49.

Cook, E.R., Woodhouse, C.A., Eakin, C.M., Meko, D.M., Stahle, D.W., 2004. Long-term aridity changes in the Western United States. Science 306 (5698), 1015-1018.

Cook, E.R., Seager, R., Heim Jr, R.R., Vose, R.S., Herweijer, C., Woodhouse, C., 2010. Megadroughts in North America: placing IPCC projections of hydroclimatic change in a long-term palaeoclimate context. J. Quat. Sci. 25 (1), 48-61.

Croker, T.C., 1979. The longleaf pine story. J. For. Hist. 23 (1), 32-43.

Detroit Publishing Co., 1900-1906, Loading a lumber schooner, Savannah, Ga. Savannah United States Georgia, edited, Retrieved from the Library of Congress, https://www. loc.gov/item/2016803976/.

Domínguez-Delmás, M., 2020. Seeing the forest for the trees: New approaches and challenges for dendroarchaeology in the 21st century. Dendrochronologia 62, 125731. https://doi.org/10.1016/j.dendro.2020.125731.

Domínguez-Delmás, M., Nayling, N., Ważny, T., Loureiro, V., Lavier, C., 2013. Dendrochronological dating and provenancing of timbers from the arade 1 Shipwreck, Portugal. Int. J. Nautical Archaeol. 42 (1), 118-136.

Douglass, A.E., 1929. Secret of the Southwest Solved by Talkative Tree Rings. In: National Geographic Magazine, edited.

East, D.C., 2013. A Historical Overview of the Forestry Industry and Clay County. <http://alabamaclaycounty.com/wp-content/uploads/2013/05/A-HISTORIC -OVERVIEW-OF-THE-FORESTRY-INDUSTRY-IN-CLAY-COUNTY.pdf $>$, edited.

Eckstein, D., Wrobel, S., 2007. Dendrochronological proof of origin of historic timber-retrospect and perspectives. Paper presented at Volume 5: Proceedings of the Symposium of Tree Rings in Archaeology, Climatology and Ecology.

Eisterhold, J.A., 1973. Savannah: Lumber Center of The South Atlantic. Georgia Hist. Q. 57 (4), 526-543.

Fickle, J.E., 2014. Green Gold: Alabama's Forests and Forest Industries, edited. University of Alabama Press, Tuscaloosa, Ala

Finch, B., Young, B.M., Johnson, R., Hall, J.C., 2012. Longleaf, Far as the Eye Can See: A New Vision of North America's Richest Forest. University of North Carolina Press.

Frost, C.C., 1993. Four centuries of changing landscape patterns in the longleaf pine ecosystem. In: Proceedings of the Tall Timbers Fire Ecology Conference, pp. 17-48.

Guiterman, C.H., Swetnam, T.W., Dean, J.S., 2016. Eleventh-century shift in timber procurement areas for the great houses of Chaco Canyon. Proc. Natl. Acad. Sci. 113 (5), 1186-1190.

Guyette, R.P., Stambaugh, M.C., Dey, D.C., Muzika, R.-M., 2012. Predicting fire frequency with chemistry and climate. Ecosystems 15 (2), 322-335.

Hawley, F.M., 1934., The significance of the dated prehistory of Chetro Ketl, Chaco Cañon, New Mexico, 80 p., [17] leaves of plates pp., University of New Mexico Press, Albuquerque, N.M.

Holmes, R., 1983. Program COFECHA User's Manual. Laboratory of Tree-Ring Research, The University of Arizona, Tucson.

Kellogg, R.S., 1909. The Timber Supply of the United States. U.S Department of Agriculture, Forest Service.

King, M., 1893. King's handbook of New York City, 1008 p. Boston, Mass.

Krusic, P.J., Wright, W.E., Cook, E.R., 2004. Tree-Ring Dating of the Cahn House New Paltz, New York, Lamont-Doherty Geological Observatory, Columbia University, New York <http://hmvarch.org/dendro/ny-ulster-cahn-newpaltz-dendro.pdf >.

Lionel Pincus and Princess Firyal Map Division, 1885. Plate 14: Bounded by W. 40th Street, Sixth Avenue, W. 27th Street and Twelfth Avenue. The New York Public Library Digital Collections.

Little, E.L., Jr., 1971., Atlas of United States trees. Volume 1. Conifers and important hardwoods., Misc. Publ. 1146. U.S. Department of Agriculture, Forest Service.

Martin-Benito, D., Pederson, N., McDonald, M., Krusic, P., Fernandez, J.M., Buckley, B., Anchukaitis, K.J., D’Arrigo, R., Andreu-Hayles, L., Cook, E., 2014. Dendrochronological Dating of the World Trade Center Ship, Lower Manhattan, New York City. Tree-Ring Res. 70 (2), 65-77, 13.

Matthews-Northrup Company, and Shenandoah Valley Railway Company, 1890. Map of the Shenandoah Valley route via Luray Caverns, Natural Bridge \& the Grottos. The Shenandoah Valley R.R. Norfolk \& Western R.R. and East Tennessee, Virginia \& Georgia System and their connections., Retrieved from the Library of Congress, $<$ https://www.loc.gov/item/98688803/>. Buffalo.

Miller, T., 2012. The Goliath 1891 Terminal Warehouse Bldgs - 11th Avenue at 27th Street. <http://daytoninmanhattan.blogspot.com/2012/09/the-goliath-1891-term inal-warehouse.html >, edited.

New York (N.Y.). Department of Docks and Ferries, 1906. Waterfront City of New York, edited by J. A. Bensel and G. H. Schwab, Dept. of Docks \& Ferries, [New York, N.Y.].

New York Times, 1902. A BIG WAREHOUSE AFIRE: Heavy Losses in the Terminal Company's Building. In: New York Times, edited, p. 7, New York City, U.S.A. < https ://www.nytimes.com/1902/05/28/archives/a-big-warehouse-afire-heavy-losses-inthe-terminal-companys.html? searchResultPosition $=3>$.

New York Times, 1912, \$500,000 BLAZE IN HUGE STORAGE PLANT; 5-Alarm Call for Fire in Terminal Warehouse, Covering a West Side Block. In: New York Times, edited, p. 1, New York City, U.S.A. <https://www.nytimes.com/1912/01/17/archi ves/500000-blaze-in-huge-storage-plant-5alarm-call-for-fire-in-terminal.html? searchResultPosition $=2>$.

Outcalt, K.W., 2000. The longleaf pine ecosystem of the South. Native Plants J. 1 (1), 42-53.

Pearl, J.K., Keck, J.R., Tintor, W., Siekacz, L., Herrick, H.M., Meko, M.D., Pearson, C.L., 2020. New frontiers in tree-ring research. The Holocene 30 (6), 923-941. 
Pederson, N., Bell, A.R., Knight, T.A., Leland, C., Malcomb, N., Anchukaitis, K.J., Tackett, K., Scheff, J., Brice, A., Catron, B., Blozan, W., Riddle, J., 2012. A long-term perspective on a modern drought in the American Southeast. Environ. Res. Lett. 7 (1), 014034. https://doi.org/10.1088/1748-9326/7/1/014034.

Pfaff, A.S.P., 2000. From Deforestation to Reforestation in New England, United States In: Palo, M., Vanhanen, H. (Eds.), World Forests from Deforestation to Transition? Springer, Netherlands, Dordrecht, pp. 67-82.

Smith, G.C., Patterson, M.W., Trendell, H.R., 2000. The demise of the longleaf-pine ecosystem. Southeastern Geogr. 40 (1), 75-92.

Speer, J.H., 2010. Fundamentals of Tree-ring Research. University of Arizona Press.

Stambaugh, M.C., Bigelow, S.W., Abadir, E.R., 2021. Linkages between forest growth, climate, and agricultural production are revealed through analysis of seasonallypartitioned longleaf pine (Pinus palustris Mill.) tree rings, 125801

Dendrochronologia 65. https://doi.org/10.1016/j.dendro.2020.125801.
Stiglitz, J.E., 2015. The price of inequality: How today's divided society endangers our future. In: Sustainable Humanity, Sustainable Nature: Our Responsibility, pp. 379-399.

Stokes, M.A., Smiley, T.L., 1968. An introduction to tree-ring dating. University of Arizona Press.

Wahlenberg, W.G., 1946. Longleaf Pine: Its Use, Ecology, Regeneration, Protection, Growth, and Management, edited.

Wigley, T.M.L., Briffa, K.R., Jones, P.D., 1984. On the average value of correlated time series, with applications in dendroclimatology and hydrometeorology. J. Clim. Appl. Meteorol. 23 (2), 201-213.

Williams, M. (1989), Americans and their forests: a historical geography, edited, Cambridge University Press, Cambridge [Cambridgeshire].

Yee, V., 2015. Salvaging a Long-Lasting Wood, and New York City's Past. In: New York Times. <https://www.nytimes.com/2015/07/22/nyregion/salvaging-a-long-last ing-wood-and-new-york-citys-past.html>, edited. 